\title{
Assessment and retrofitting of nursing faculty building of Andalas University, Padang, Indonesia
}

\author{
Fauzan Fauzan ${ }^{1 *}$, Dina Yarmawati $^{2}$, Seno Willy Dharma Sipayung ${ }^{1}$, Willy Kurniawan ${ }^{1}$, and Rozi Adifa ${ }^{1}$ \\ ${ }^{1}$ Department of Civil Engineering, Faculty of Engineering, University of Andalas, Padang. \\ ${ }^{2}$ Department of Civil and Environmental Engineering, School of Engineering, Tokyo Institute of Technology, Tokyo, Japan
}

\begin{abstract}
The Faculty of Nursing building is one of the administrative buildings at Andalas University. This building was designed by a planning consultant and began construction in 2013 . However, during the construction period, it was found that the concrete quality was very low, that is $\mathrm{fc}^{\prime}=14.32 \mathrm{MPa}$, so that the construction could not be continued because it was not in accordance with the planning quality, $\mathrm{fc}^{\prime}=22.39 \mathrm{MPa}$. Therefore, it is necessary to evaluate the feasibility of the building structure before the construction is continued. In the structural analysis, the loads apllied are dead loads, live loads, and earthquake loads. The analysis was carried out using the application (software) ETABS. Based on the analysis results, it was found that the capacity of columns and beams of the building are not strong enough to withstand the loads acting on the structure. The inter story drift also does not meet the permit limit requirements according to the New Indonesian Earthquake Code, SNI 1726:2019. Therefore, it is necessary to retrofit (strengthen) the structure of the Nursing Faculty Building by re-designing the Detail Engineering Design (DED) on the beams and columns of the plan and jacketing the existing columns. Re-analysis results show that the retrofitted building structure has a strong enough capacity to carry loads acting on the structure and the inter story drift has met the permit limit requirements according to the SNI 1726:2019.
\end{abstract}

\section{Introduction}

The Faculty of Nursing building is one of the administrative buildings at Andalas University. This building was designed by a planning consultant and began construction in 2013. However, during the construction period, it was found that the concrete quality was very low, that is $\mathrm{fc}^{\prime}=14.32 \mathrm{Mpa}$, so that the construction could not be continued because it was not in accordance with the planning quality, $\mathrm{fc}^{\prime}=22.39 \mathrm{MPa}$ [1]. The demolition of the building certainly requires a large amount of money. Therefore, it is necessary to have an action to retrofit (strengthen) the structure so that the building can carry the working load.

Therefore, it is necessary to assess of the structure and design retrofitting the structure of the Nursing Faculty Building, Andalas University.

\section{Evaluation of Existing Structure}

\subsection{Condition of Existing Structure}

The existing structure of the Nursing Faculty Building, Andalas University consists of the foundation, slab and first floor columns, as shown in Fig. 1.

\footnotetext{
* Corresponding author: fauzan@eng.unand.ac.id
}

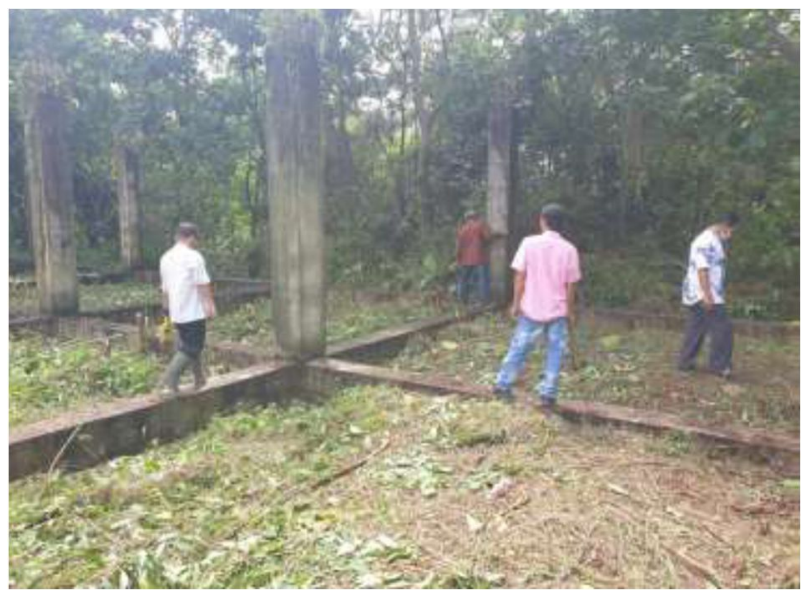

Fig. 1. Existing Building Condition

From a field survey on the existing structure, it is found that the steel reinforcement had corroded (Fig. 2) and the concrete has porous and overgrown with moss (Figs. 3 and 4). From the concrete quality test results using a hammer test, the average concrete quality is $\mathrm{fc}^{\prime}=11.24$ $\mathrm{MPa}$, where the quality of this concrete is not in accordance with the design concrete quality. 


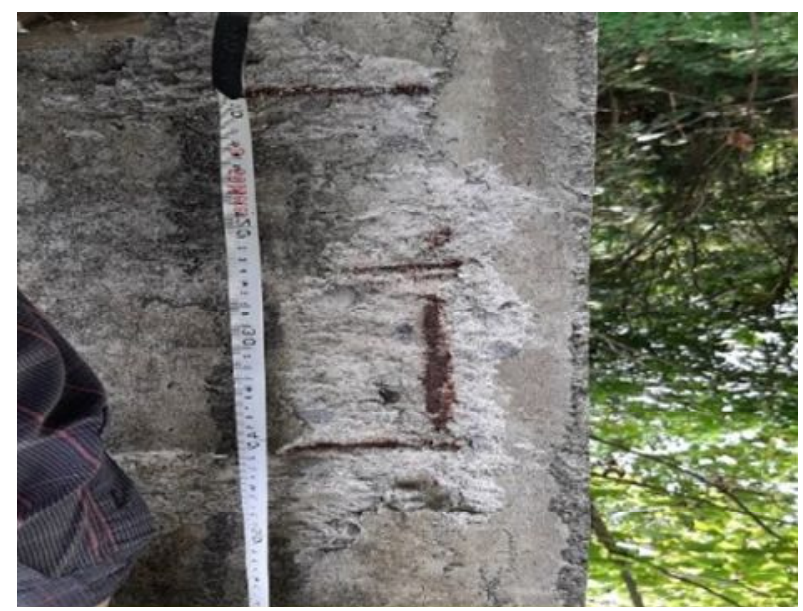

Fig. 2. Steel Reinforcement Corrosion

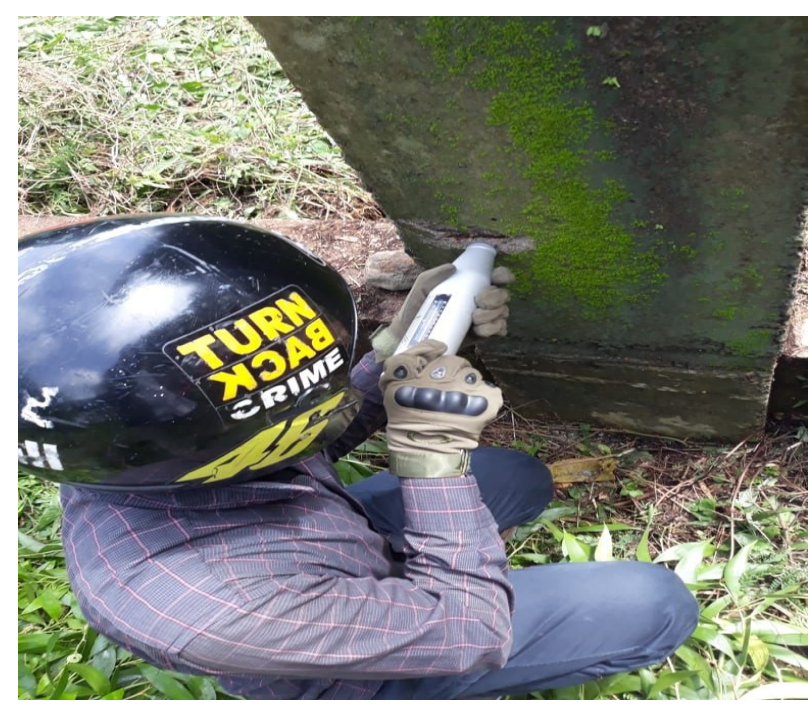

Fig. 3. The Concrete Surface is Overgrown with Moss

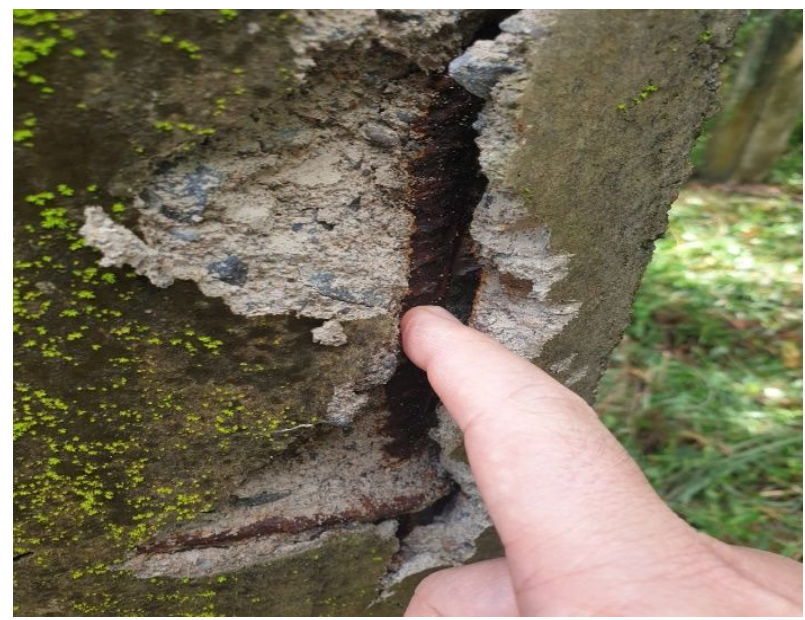

Fig. 4. Porous Concrete and Rusty Steel Reinforcement

\subsection{Structural System}

The structural type of the Nursing Faculty Building, Andalas University, is a reinforced concrete structure. The building risk category is type IV because the building is classified as an educational facility building with seismic design category $\mathrm{D}$, so the structural system used in the analysis is a special moment resisting reinforced concrete frame system.

\subsection{Building Structure Data}

Data on the structure of the Nursing Faculty Building can be seen in Table 1.

Table 1. Building data

\begin{tabular}{|c|c|}
\hline Name Of Building & Nursing Faculty Building of Andalas University \\
\hline Addres & Limau Manis, Padang \\
\hline Structure Type & Concrete Reinforced \\
\hline Design Concrete Quality & $\mathrm{fc}^{\prime}=22,39 \mathrm{MPa}$ \\
\hline Eksisting Concrete Quality & $\mathrm{fc}^{\prime}=11,24 \mathrm{MPa}$ \\
\hline Number Of Stories & 2 stories with concrete slab \\
\hline Building Height & 8 Meter \\
\hline Column Dimension & . Main Column (K1): $(40 \times 40) \mathrm{cm}$ \\
\hline \multirow{2}{*}{ Beam Dimension } & . $\quad$ Main Beam $(\mathrm{BA}):(30 \times 50) \mathrm{cm}$ \\
\hline & - Secondary Beam (BA-1): $(20 \times 30) \mathrm{cm}$ \\
\hline Slab Thickness & $12 \mathrm{~cm}$ \\
\hline Length & $2600 \mathrm{~cm}$ \\
\hline Width & $2200 \mathrm{~cm}$ \\
\hline
\end{tabular}

\subsection{Modeling of Structure}

Analysis of the Nursing Faculty Building structure, Andalas University, was carried out using 3D structural modeling in the ETABS program. Columns and beams of the building structure are modeled as frame elements, while the slabs are modeled as slab elements.

The results of the modeling of the building structure can be seen in Fig. 5 .

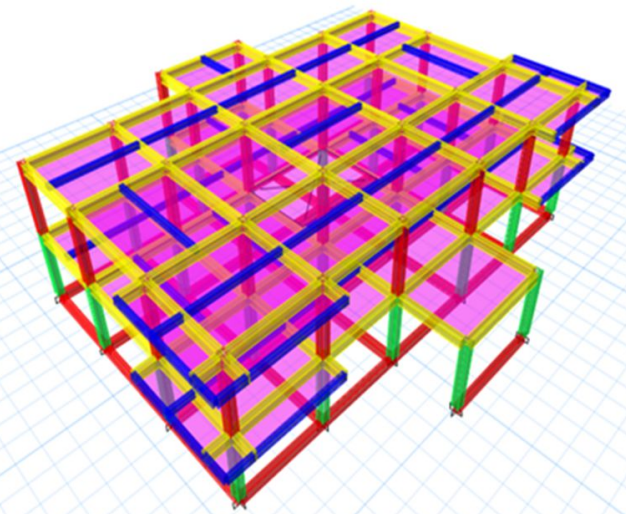

Fig. 5. Modeling of Structure

\subsection{Building Loads}

\subsubsection{Dead Load}

Based on Article 3.1.1 of SNI 1727:2020, the dead load is defined as the weight of all installed building construction materials, including walls, floors, roofs, ceilings, stairs, fixed partition walls, finishing, building cladding, and 
other architectural and structural components as well as service equipment. Other installed equipment includes crane weights and material conveying systems [2].

Dead loads on the Nursing Faculty Building:

a. Self-weight of structural elements is calculated directly by the ETABS structural analysis program version 2016.

b. Weight of floor covering (ceramic) $1 \mathrm{~cm}$ thick $=1 \mathrm{x}$ $24 \mathrm{~kg} / \mathrm{m}^{2}=24 \mathrm{~kg} / \mathrm{m}^{2}$

c. Ceiling weight $=20 \mathrm{~kg} / \mathrm{m}^{2}$

d. Flooring mortar $2 \mathrm{~cm}$ thick floor $=2 \times 21 \mathrm{~kg} / \mathrm{m}^{2}=42$ $\mathrm{kg} / \mathrm{m}^{2}$

e. Mechanical Electrical and Plumbing weight $=25$ $\mathrm{kg} / \mathrm{m}^{2}$

f. Waterproofing weight $=5 \mathrm{~kg} / \mathrm{m}^{2}$

\subsubsection{Live Load}

Article 4.3.1 of SNI 1727:2020 explains that the live load used in the design of buildings and other structures must be the maximum load that is expected to occur due to the occupancy and use of the building, but it must not be less than the minimum uniform load specified in Table 4.3.1 on SNI 1727:2020 [2]. The live loads acting on the building:

1. Corridor above first floor $=3.83 \mathrm{kN} / \mathrm{m}^{2}$

2. Office $=2.4 \mathrm{kN} / \mathrm{m}^{2}$

3. Meeting room $=4.79 \mathrm{kN} / \mathrm{m}^{2}$

4. Toilet $=2.87 \mathrm{kN} / \mathrm{m}^{2}$

\subsubsection{Brick Wall Load}

In addition to the dead load acting on the floor of the building, another load acting on the building is the brick wall. According to SNI 1727:2020, the load on the brick walls working on the building is $250 \mathrm{~kg} / \mathrm{m}^{2}$ while the wall height is $4 \mathrm{~m}$, so the uniform load acting on the building with brick walls is $4 \mathrm{~m} \times 250 \mathrm{~kg} / \mathrm{m}^{2}=1000 \mathrm{~kg} / \mathrm{m}$ [2].

\subsubsection{Partition Loads}

Based on SNI 1727:2019 Article 4.3.2, it can be seen that the partition load is at least $72 \mathrm{~kg} / \mathrm{m}^{2}$ [2]. So that for the Nursing Faculty Building, it is assumed that the partition weight is $80 \mathrm{~kg} / \mathrm{m}^{2}$ and for the height of the building between floors is 4 meters, the partition load acting on the floor beams of the Nursing Faculty Building is $4 \mathrm{~m} \times 80$ $\mathrm{kg} / \mathrm{m}^{2}=320 \mathrm{~kg} / \mathrm{m}^{2}(3.14 \mathrm{kN} / \mathrm{m})$.

\subsubsection{Earthquake Loads}

Earthquake load analysis is conducted based on SNI 1726:2019 [3]. The type of earthquake load used in the design of the structure is dynamic earthquake load. The dynamic earthquake load used in building structures is the response spectrum. The earthquake spectrum response data itself is obtained from the RSA Puskim PUPR application. The Nursing Faculty Building is located in Padang city. The response spectrum data is shown in Tables 2 and 3.
Table 2. Spectra data (Source: PUSKIM PUPR RSA Application)

\begin{tabular}{|l|l|}
\hline \multicolumn{1}{|c|}{ Variable } & Value \\
\hline PGA $(g)$ & 0.588 \\
\hline $\mathrm{S}_{\mathrm{S}}(\mathrm{g})$ & 1.480 \\
\hline $\mathrm{S}_{1}(\mathrm{~g})$ & 0.600 \\
\hline $\mathrm{C}_{\mathrm{RS}}$ & 0.000 \\
\hline $\mathrm{C}_{\mathrm{R} 1}$ & 0.000 \\
\hline $\mathrm{F}_{\mathrm{PGA}}$ & 1.000 \\
\hline $\mathrm{F}_{\mathrm{A}}$ & 1.000 \\
\hline $\mathrm{F}_{\mathrm{V}}$ & 1.700 \\
\hline $\mathrm{PSA}(\mathrm{g})$ & 0.536 \\
\hline $\mathrm{S}_{\mathrm{MS}}(\mathrm{g})$ & 1.480 \\
\hline $\mathrm{S}_{\mathrm{M} 1}(\mathrm{~g})$ & 1.020 \\
\hline $\mathrm{S}_{\mathrm{DS}}(\mathrm{g})$ & 0.987 \\
\hline $\mathrm{S}_{\mathrm{D} 1}(\mathrm{~g})$ & 0.680 \\
\hline $\mathrm{T}_{0}$ & 0.138 \\
\hline $\mathrm{T}_{\mathrm{S}}$ & 0.689 \\
\hline
\end{tabular}

Table 3. Spectrum response period

\begin{tabular}{|c|c|}
\hline Period $(\mathrm{T})$ & $\mathrm{Sa}(\mathrm{g})$ \\
\hline 0.000 & 0.000 \\
\hline 0.100 & 0.824 \\
\hline 0.300 & 0.987 \\
\hline 0.500 & 0.987 \\
\hline 1.000 & 0.680 \\
\hline 1.500 & 0.453 \\
\hline 2.000 & 0.340 \\
\hline 2.500 & 0.272 \\
\hline 3.000 & 0.227 \\
\hline 4.000 & 0.170 \\
\hline
\end{tabular}

These tables are dynamic earthquake data obtained from the Puskim PU application. From these data, a graph of Earthquake Response Spectrum Design of Padang City was obtained, as shown in Fig. 6.

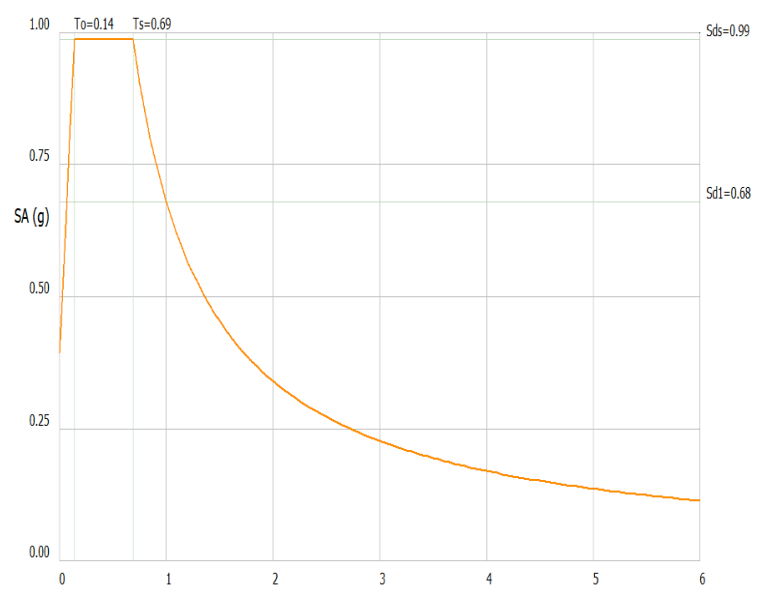

Fig. 6. Earthquake Response Spectrum Design of Padang City 


\subsection{Load Combination}

The combination of structural loading refers to the SNI 1726:2019 [3]:

1. $1,4 \mathrm{D}$

2. $1.2 \mathrm{D}+1.6 \mathrm{~L}+0.5(\mathrm{Lr}$ or $\mathrm{R})$

3. $1.2 \mathrm{D}+1.6(\mathrm{Lr}$ or $\mathrm{R})+(\mathrm{L}$ or $0.5 \mathrm{~W})$

4. $1.2 \mathrm{D}+1.0 \mathrm{~W}+\mathrm{L}+0.5(\mathrm{Lr}$ or $\mathrm{R})$

5. $0.9 \mathrm{D}+1.0 \mathrm{~W}$

6. $1,2 \mathrm{D}+\mathrm{EV}+\mathrm{EH}+\mathrm{L}$

7. $0.9 \mathrm{D}-\mathrm{EV}+\mathrm{EH}$

Table 4. Load combination

\begin{tabular}{|c|c|c|c|c|c|c|c|c|c|c|c|}
\hline \multicolumn{12}{|c|}{ Loads Combination } \\
\hline 1 & 1.4 & DL & & & & & & & & & \\
\hline 2 & 1.2 & DL & + & 1.6 & $\mathrm{LL}$ & & & & & & \\
\hline 3 & 1.397 & DL & + & 1 & $\mathrm{LL}$ & + & 1.3 & EQX & + & 0.39 & EQY \\
\hline 4 & 1.397 & DL & + & 1 & LL & + & 1.3 & EQX & - & 0.39 & EQY \\
\hline 5 & 1.397 & DL & + & 1 & $\mathrm{LL}$ & - & 1.3 & EQX & + & 0.39 & EQY \\
\hline 6 & 1.397 & DL & + & 1 & $\mathrm{LL}$ & - & 1.3 & EQX & - & 0.39 & EQY \\
\hline 7 & 1.397 & DL & + & 1 & $\mathrm{LL}$ & + & 0.39 & EQX & + & 1.3 & EQY \\
\hline 8 & 1.397 & DL & + & 1 & $\mathrm{LL}$ & + & 0.39 & EQX & - & 1.3 & EQY \\
\hline 9 & 1.397 & DL & + & 1 & $\mathrm{LL}$ & - & 0.39 & EQX & + & 1.3 & EQY \\
\hline 10 & 1.397 & DL & + & 1 & LL & - & 0.39 & EQX & - & 1.3 & EQY \\
\hline 11 & 0.703 & DL & + & 1.3 & EQX & + & 0.39 & EQY & & & \\
\hline 12 & 0.703 & DL & + & 1.3 & EQX & - & 0.39 & EQY & & & \\
\hline 13 & 0.703 & DL & - & 1.3 & EQX & + & 0.39 & EQY & & & \\
\hline 14 & 0.703 & DL & - & 1.3 & EQX & - & 0.39 & EQY & & & \\
\hline 15 & 0.703 & DL & + & 0.39 & EQX & + & 1.3 & EQY & & & \\
\hline 16 & 0.703 & DL & + & 0.39 & EQX & - & 1.3 & EQY & & & \\
\hline 17 & 0.703 & DL & - & 0.39 & EQX & + & 1.3 & EQY & & & \\
\hline 18 & 0.703 & DL & - & 0.39 & EQX & - & 1.3 & EQY & & & \\
\hline 19 & Envelope & & & & & & & & & & \\
\hline
\end{tabular}

Table 4 shows the load combinations in the structural analysis of the Nursing Faculty Building.

\subsection{Inter Story Drift}

Table 5. Inter story drift limit (Source: SNI 1726:2019)

\begin{tabular}{|l|c|c|c|}
\hline \multirow{2}{*}{ Structure } & \multicolumn{3}{|c|}{ Risk Category } \\
\cline { 2 - 4 } & I or II & III & IV \\
\hline $\begin{array}{l}\text { Structures, other than brick shear wall structures, } 4 \text { stories or } \\
\text { less with interior walls, partitions, ceilings and exterior wall } \\
\text { system which has been designed for accommodate deviations } \\
\text { between levels. }\end{array}$ & $0,025 \mathrm{~h}_{\mathrm{sx}}$ & $0,020 \mathrm{~h}_{\mathrm{sx}}$ & $0,015 \mathrm{~h}_{\mathrm{sx}}$ \\
\hline Brick cantilever shear wall structure & $0,010 \mathrm{~h}_{\mathrm{sx}}$ & $0,010 \mathrm{~h}_{\mathrm{sx}}$ & $0,010 \mathrm{~h}_{\mathrm{sx}}$ \\
\hline Other brick shear wall structures & $0,007 \mathrm{~h}_{\mathrm{sx}}$ & $0,007 \mathrm{~h}_{\mathrm{sx}}$ & $0,007 \mathrm{~h}_{\mathrm{sx}}$ \\
\hline All other structures & $0,020 \mathrm{~h}_{\mathrm{sx}}$ & $0,015 \mathrm{~h}_{\mathrm{sx}}$ & $0,010 \mathrm{~h}_{\mathrm{sx}}$ \\
\hline
\end{tabular}

Table 5 shows the boundary conditions for the inter story drift for the building. From the equation in the table, the calculation results of the building inter story drift are shown in Tables 6 and 7.

Table 6. Inter story drift $\mathrm{X}$ direction

\begin{tabular}{|c|c|c|c|c|c|c|c|c|}
\hline \multirow{2}{*}{ Story } & \multirow{2}{*}{ Direction } & $\delta_{\mathrm{e}}$ & \multirow{2}{*}{$\mathrm{Cd}$} & $\delta_{\text {es }}$ & $\Delta_{\mathrm{I}}$ & Height & $\Delta$ (timit) & \multirow{2}{*}{ Description } \\
\hline & & $\mathrm{mm}$ & & $\mathrm{mm}$ & $\mathrm{mm}$ & $\mathrm{mm}$ & $\mathrm{mm}$ & \\
\hline 2 & X & 31,393 & 5.5 & 115.10767 & 52.7817 & 4000 & 40 & NOTOK \\
\hline 1 & $X$ & 16.998 & 5.5 & 62.326 & 62.326 & 4000 & 40 & NOTOK \\
\hline 0 & X & 0 & 5.5 & 0 & 0 & 4000 & 40 & OK \\
\hline
\end{tabular}

Table 7. Inter story drift Y direction

\begin{tabular}{|c|c|c|c|c|c|c|c|c|}
\hline \multirow{2}{*}{ Story } & \multirow{2}{*}{ Direction } & $\delta_{\mathrm{e}}$ & \multirow{2}{*}{$\mathrm{Cd}$} & $\delta_{\mathrm{ex}}$ & $\Delta_{Y}$ & Height & $\Delta$ (Limit) & \multirow{2}{*}{ Description } \\
\hline & & $\mathrm{mm}$ & & $\mathrm{mm}$ & $\mathrm{mm}$ & $\mathrm{mm}$ & $\mathrm{mm}$ & \\
\hline 2 & $Y$ & 30.403 & 5.5 & 111.4777 & 51.5167 & 4000 & 40 & NOTOK \\
\hline 1 & $\mathrm{Y}$ & 16.353 & 5.5 & \begin{tabular}{|l|}
59.961 \\
\end{tabular} & 59.961 & 4000 & 40 & NOTOK \\
\hline 0 & $Y$ & 0 & 5.5 & 0 & 0 & 4000 & 40 & OK \\
\hline
\end{tabular}

From Tables 6 and 7, it can be seen that the inter story drift that occurs in the building does not meet the permit limit requirements in SNI 1726:2019.

\subsection{Cross-sectional Capacity of the Structure}

\subsubsection{Column Capacity}

The capacity of the column is determined through the interaction diagram of the axial moment and compression of the column and the shear capacity of the column [4].

\section{a. Momen and Axial of Column}

The calculation results of the interaction diagram of the first floor and second floor columns of the building are shown in Figs. 7 and 8.

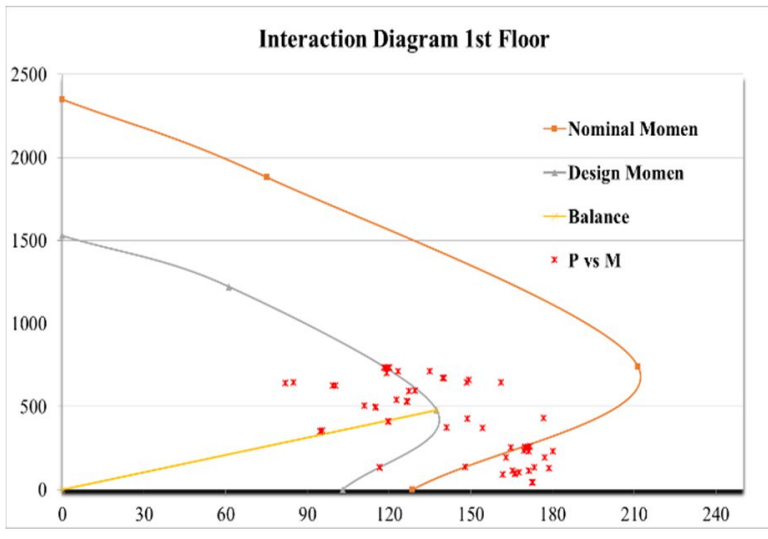

Fig. 7. First Floor Column P-M Interaction Diagram

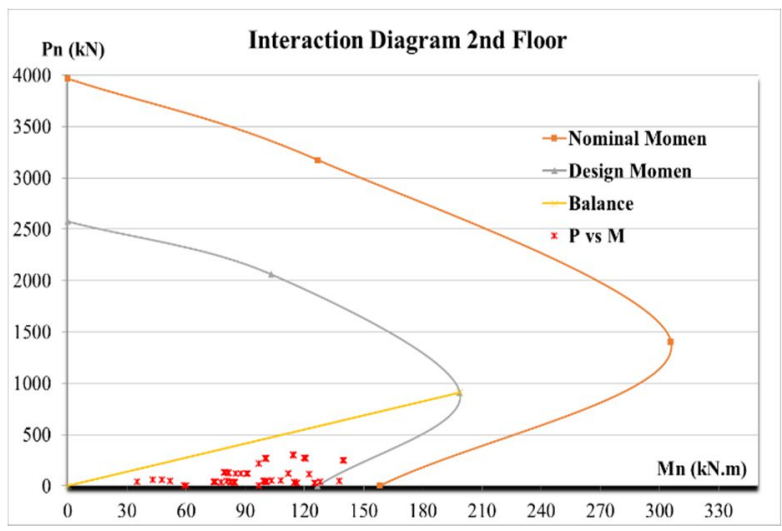

Fig. 8. Second Floor Column P-M Interaction Diagram

As seen in Figs. 7 and 8, the first and second floor columns are not strong enough to carry the working load because some axial moment and compression forces pass through the design axial compression moment line. 


\section{b. Shear Capacity of Columns}

The shear capacity of the building columns is shown in Table 8 . From the table, it is clearly seen that the column is able to withstand the shear forces acting on the structure.

Table 8. Shear capacity column

\begin{tabular}{|c|c|c|c|c|c|c|c|}
\hline & Dimension $(\mathrm{mm})$ & Fy & Dim. Shear Reinforced & Spasi & $\phi \mathrm{V} n$ & $\mathrm{Vu}$ & Description \\
\hline 1 & $400 \times 400$ & 310 & 10 & 100 & 2250.719 & 101.1666 & OK \\
\hline 2 & $400 \times 400$ & 400 & 10 & 100 & 2542.005 & 138.0258 & OK \\
\hline
\end{tabular}

\subsubsection{Beam Capacity}

\section{a. Flexural Capacity of Beams}

Table 9 shows the flexural capacity of the building beams.

Table 9. Beam flexure capacity

\begin{tabular}{|c|c|c|c|c|c|c|c|c|}
\hline \multirow{2}{*}{ Type (Dimension) } & \multirow{2}{*}{ Location } & \multicolumn{2}{|c|}{ Main Reinforced } & \multicolumn{2}{|c|}{$\begin{array}{c}\text { Nominal Flexural } \\
\text { Capacity }\end{array}$} & \multicolumn{2}{|c|}{ Ultimate Flexural Forces } & \multirow{2}{*}{ Description } \\
\hline & & At Suppor & At Fielc & At Suppor & At Field & At Support & At Field & \\
\hline \multirow{2}{*}{ Sloof (30X50) } & Top & $4 \mathrm{D} 16$ & 4D16 & 116.89 & 116.89 & 60.07 & 15.02 & \multirow{2}{*}{ OK } \\
\hline & Bottom & $4 \mathrm{D} 16$ & $4 \mathrm{D} 16$ & 116.89 & 116.89 & 30.03 & 30.03 & \\
\hline \multirow{2}{*}{ 1st floor Beam (30X50) } & Top & $6 \mathrm{D} 16$ & $4 \mathrm{D} 16$ & 181.37 & 125.00 & 228.83 & 64.17 & \multirow{2}{*}{ NOTOK } \\
\hline & Bottom & $4 \mathrm{D} 16$ & $6 \mathrm{D} 16$ & 125.00 & 181.37 & 162.12 & 37.57 & \\
\hline \multirow{2}{*}{ 2nd floor Beam (30X50) } & Top & $6 \mathrm{D} 16$ & $4 \mathrm{D} 16$ & 181.37 & 125.00 & 150.30 & 37.57 & \multirow{2}{*}{ OK } \\
\hline & Bottom & $4 \mathrm{D} 16$ & $6 \mathrm{D} 16$ & 125.00 & 181.37 & 93.85 & 82.35 & \\
\hline \multirow{2}{*}{ 1st floor Ba-1 (20x30) } & Top & $5 \mathrm{D} 16$ & $3 \mathrm{D} 16$ & 74.92 & 49.56 & 63.69 & 15.92 & \multirow{2}{*}{ NOT OK } \\
\hline & Bottom & 3D16 & 5D16 & 49.56 & 74.92 & 81.70 & 98.43 & \\
\hline \multirow{2}{*}{ 2st floor Ba-1 (20x30) } & Top & $5 \mathrm{D} 16$ & 3D16 & 74.92 & 49.56 & 64.59 & 16.15 & \multirow{2}{*}{ NOT OK } \\
\hline & Bottom & 3D16 & $5 \mathrm{D} 16$ & 49.56 & \begin{tabular}{|l|}
74.92 \\
\end{tabular} & 44.57 & 85.32 & \\
\hline
\end{tabular}

From Table 9, it can be seen that the beams on the first floor and the beams on the first and second floors are unable to withstand the loads acting on the structure.

\section{b. Shear Capacity of Beams}

The shear capacity of the building beams can be seen in Table 10. From the table, it is found that the beam is able to withstand the shear forces acting on the structure.

Table 10. Beam shear capacity

\begin{tabular}{|l|c|c|c|c|c|c|c|}
\hline \multirow{2}{*}{ Type (Dimension) } & \multicolumn{2}{|c|}{ Shear Reinforced } & \multicolumn{2}{c|}{$\begin{array}{c}\text { Nominal Shear } \\
\text { Capacity }\end{array}$} & \multicolumn{2}{c|}{$\begin{array}{c}\text { Ultimate Shear } \\
\text { Forces }\end{array}$} & \multirow{2}{*}{ Description } \\
\cline { 2 - 7 } & $\begin{array}{c}\text { At } \\
\text { Support }\end{array}$ & At Field & $\begin{array}{c}\text { At } \\
\text { Support }\end{array}$ & At Field & $\begin{array}{c}\text { At } \\
\text { Support }\end{array}$ & At Field & \\
\hline Sloof (30X50) & $\emptyset 10-100$ & $\emptyset 10-150$ & 366.14 & 269.79 & 25.65 & 55.02 & OK \\
\hline 1st floor Beam(30X50) & $\varnothing 10-100$ & $\emptyset 10-150$ & 397.86 & 301.52 & 243.54 & 219.82 & OK \\
\hline 2nd floor Beam (30X50) & $\varnothing 10-100$ & $\emptyset 10-100$ & 397.86 & 301.52 & 143.20 & 117.88 & OK \\
\hline 1st floor Ba-1 (20x30) & $\emptyset 12-100$ & $\emptyset 10-150$ & 276.25 & 149.92 & 82.27 & 50.23 & OK \\
\hline 2nd floor Ba-1 (20x30) & $\emptyset 12-100$ & $\emptyset 10-150$ & 276.25 & 149.92 & 71.20 & 52.08 & OK \\
\hline
\end{tabular}

Based on the examination of the mass participation factor, scale factor, P-delta, and structural irregularities, all of them have met the requirements of SNI 1726:2019 [3].

From the evaluation results of the structural building performance, it was found that the structure of the columns and beams could not resist the loads acting on the structure. In addition, the inter story drift that occurred did not meet the permit limit requirements according to
Indonesian building standards. Therefore, the building should be retrofitted before continuing the construction.

\section{Retrofitting of the Structure}

Analysis of the retrofitting/strengthening of the structure in this building is by re-design the Detail Engineering Design (DED) of the structure where the existing columns are jacketed [5-7]. The re-design is carried out on the beams, the second-floor column, while the first-floor column is retrofitted using the jacketing method.

\subsection{Beam}

Re-design of beams was carried out on the structure of the main and secondary beams of the building. The re-design was carried out because the beams from the initial design (DED) could not withstand the loads acting on the structure $[4,8]$.

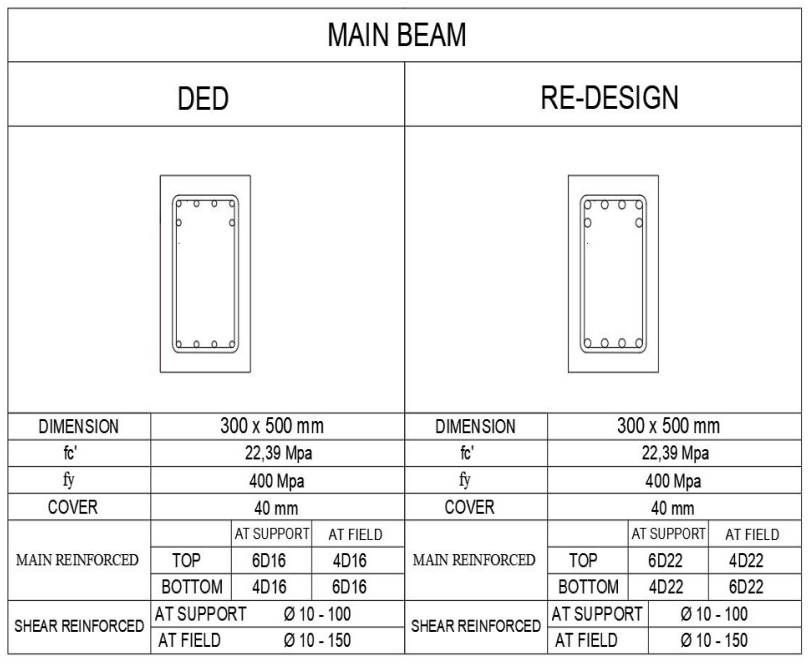

Fig. 9. Comparison of the Main Beam Details between the DED (Initial Design) and the Re-design

\begin{tabular}{|c|c|c|c|c|c|c|c|}
\hline \multicolumn{8}{|c|}{ SECONDARY BEAM } \\
\hline \multicolumn{4}{|c|}{ DED } & \multicolumn{4}{|c|}{ RE-DESIGN } \\
\hline & 60 & & & & م00 & & \\
\hline DIMENSION & \multicolumn{3}{|c|}{$200 \times 300 \mathrm{~mm}$} & DIMENSION & \multicolumn{3}{|c|}{$250 \times 400 \mathrm{~mm}$} \\
\hline $\mathrm{fc}^{\prime}$ & \multicolumn{3}{|c|}{$22,39 \mathrm{Mpa}$} & $\mathrm{fc}^{\prime}$ & \multicolumn{3}{|c|}{ 22,39 Mpa } \\
\hline fy & \multicolumn{3}{|c|}{$400 \mathrm{Mpa}$} & fy & \multicolumn{3}{|c|}{$400 \mathrm{Mpa}$} \\
\hline COVER & \multicolumn{3}{|c|}{$40 \mathrm{~mm}$} & COVER & \multicolumn{3}{|c|}{$40 \mathrm{~mm}$} \\
\hline \multirow{3}{*}{ MAIN REINORCED } & & AT SUPPORT & AT FIELD & \multirow{3}{*}{ MAIN REINFORCED } & & AT SUPPORT & AT FIELD \\
\hline & TOP & $5 \mathrm{D} 16$ & $3 D 16$ & & TOP & $4 \mathrm{D} 22$ & $3 \mathrm{D} 22$ \\
\hline & BOTTOM & $3 D 16$ & $5 \mathrm{D} 16$ & & BOTTOM & 3022 & $4 \mathrm{D} 22$ \\
\hline \multirow{2}{*}{ SHEAR RENFORCED } & AT SUPPO & & $\varnothing 12-100$ & \multirow{2}{*}{ SHEARREINFORCED } & AT SUPPO & & $\varnothing 12-100$ \\
\hline & AT FIELD & & $\varnothing 10-150$ & & AT FIELD & & $\varnothing 10-150$ \\
\hline
\end{tabular}

Fig. 10. Comparison of the Secondary Beam Details between the DED (Initial Design) and the Re-design 
Figs. 9 and 10 show the comparison of the details of the main beam between the initial design (DED) and the Re-design.

\subsubsection{Re-designed Beam Capacity}

\section{a. Flexural Capacity}

The results of the beam flexural capacity analysis are shown in Table 11.

Table 11. Re-designed beam flexural capacity

\begin{tabular}{|c|c|c|c|c|c|c|c|c|}
\hline \multirow{2}{*}{ Type (Dimension) } & \multirow{2}{*}{ Location } & \multicolumn{2}{|c|}{ Main Reinforced } & \multicolumn{2}{|c|}{$\begin{array}{c}\text { Nominal Flexural } \\
\text { Capacity }\end{array}$} & \multicolumn{2}{|c|}{\begin{tabular}{|c}
$\begin{array}{c}\text { Ultimate Flexural } \\
\text { Forces }\end{array}$ \\
\end{tabular}} & \multirow{2}{*}{ Description } \\
\hline & & $\begin{array}{c}\text { At } \\
\text { Support }\end{array}$ & At Field & $\begin{array}{c}\text { At } \\
\text { Support }\end{array}$ & At Field & $\begin{array}{c}\text { At } \\
\text { Support }\end{array}$ & At Field & \\
\hline \multirow{2}{*}{ Sloof (30X50) } & Top & $4 \mathrm{D} 16$ & 4D16 & 116.89 & 116.89 & 60.07 & 15.02 & \multirow{2}{*}{ OK } \\
\hline & Bottom & 4D16 & 4D16 & 116.89 & 116.89 & 30.03 & 30.03 & \\
\hline \multirow{2}{*}{ 1st floor Beam (30X50) } & Top & 6D22 & 4D22 & 311.90 & 222.56 & 178.07 & 44.52 & \multirow{2}{*}{ OK } \\
\hline & Bottom & 4D22 & 6D22 & 222.56 & 311.90 & 98.20 & 137.82 & \\
\hline \multirow{2}{*}{ 2nd floor Beam (30X50) } & Top & 6D22 & 4D22 & 311.90 & 222.56 & 149.82 & 37.46 & \multirow{2}{*}{ OK } \\
\hline & Bottom & 4D22 & 6D22 & 222.56 & 311.90 & 97.08 & 81.66 & \\
\hline \multirow{2}{*}{ 1st floor Ba-1 (20x30) } & Top & $4 \mathrm{D} 22$ & $3 \mathrm{D} 22$ & 161.97 & 128.06 & 73.67 & 24.92 & \multirow{2}{*}{ OK } \\
\hline & Bottom & 3D22 & 4D22 & 128.06 & 161.97 & 84.52 & 158.07 & \\
\hline \multirow{2}{*}{ 2st floor Ba-1 (20x30) } & Top & $4 \mathrm{D} 22$ & $3 \mathrm{D} 22$ & 161.97 & 128.06 & 72.56 & 18.14 & \multirow{2}{*}{ OK } \\
\hline & Bottom & 3D22 & $4 \mathrm{D} 22$ & 128.06 & 161.97 & 47.85 & 91.23 & \\
\hline
\end{tabular}

From Table 11, it can be seen that all the beam structures after the re-design have been able to withstand the loads acting on the structure.

\section{b. Shear Capacity}

Table 12 shows the results of the beam shear capacity analysis.

Table 12. Re-design beam shear capacity

\begin{tabular}{|c|c|c|c|c|c|c|c|}
\hline \multirow{2}{*}{ Tipe(Dimensi) } & \multicolumn{2}{|c|}{ Shear Reinforced } & \multicolumn{2}{|c|}{$\begin{array}{c}\text { Nominal Shear } \\
\text { Capacity }\end{array}$} & \multicolumn{2}{|c|}{$\begin{array}{c}\text { Ultimate Shear } \\
\text { Forces }\end{array}$} & \multirow{2}{*}{ Description } \\
\hline & At Support & At Field & $\begin{array}{c}\text { At } \\
\text { Suppoit }\end{array}$ & AtField & $\begin{array}{c}\text { At } \\
\text { Suppoit } \\
\end{array}$ & At Field & \\
\hline Sloof(30X50) & $\emptyset 10-100$ & $\emptyset 10-150$ & 366.14 & 269.79 & 25.65 & 55.02 & OK \\
\hline 1st floor Beam(30X50) & $\emptyset 10-100$ & Ø10-150 & 397.86 & 301.52 & 240.66 & 190.41 & OK \\
\hline 2nd floor Beam (30X50) & $\emptyset 10-100$ & $\emptyset 10-100$ & 397.86 & 301.52 & 146.26 & 123.36 & OK \\
\hline 1st floor Ba-1 (20x30) & $\emptyset 12 \cdot 100$ & $010-150$ & 396.70 & 221.77 & 93.19 & 34.88 & OK \\
\hline 2nd floor Ba-1 (20x30) & $\emptyset 12 \cdot 100$ & $010-150$ & 396.70 & 221.77 & 51.36 & 48.95 & OK \\
\hline
\end{tabular}

From Table 12, it is found that the re-designed beam is able to withstand shear forces due to external loads on the structure.

\subsection{Second Floor Column}

\begin{tabular}{|c|c|c|c|}
\hline \multicolumn{3}{|c|}{ SECOND FLOOR COLUMN } \\
\hline \multicolumn{2}{|c|}{ DED } & \multicolumn{2}{|c|}{ RE-DESIGN } \\
\hline \multicolumn{3}{|c|}{} \\
\hline
\end{tabular}

Fig. 11. Initial design (DED) and Re-design Column Details

The re-design of columns was carried out on the second floor columns of the building because the capacity of the planned columns could not withstand the working loads, so the dimensions and reinforcement of the column had to be changed $[4,8]$.

A detailed comparison between the initial design (DED) and re-designed second floor columns can be seen in Fig. 11.

\subsubsection{Column Capacity}

Fig. 12 shows the second floor column P-M interaction diagram.

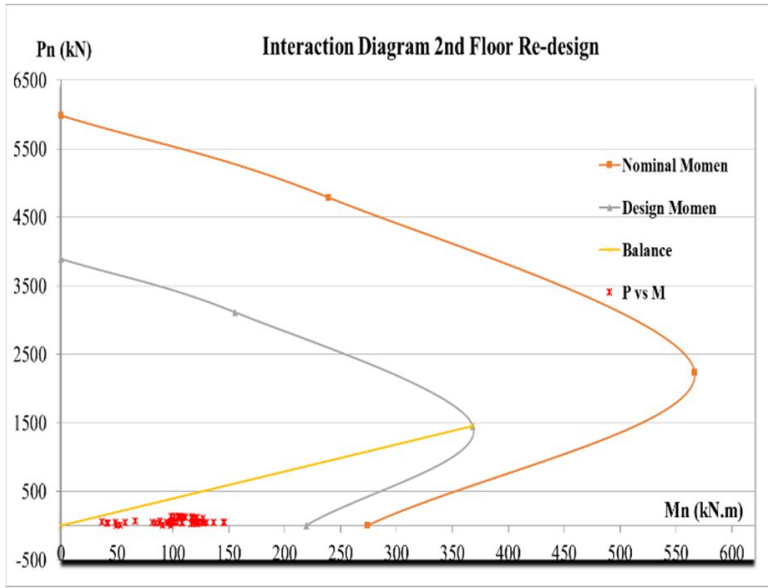

Fig. 12. Second Floor Column P-M Interaction Diagram Redesign

As seen in Fig. 12, all P-M values on the graph have been in the interaction diagram line indicating that all building columns are capable of carrying the working load. 


\subsection{Retrofitting of First Floor Column using Jacketing Method}

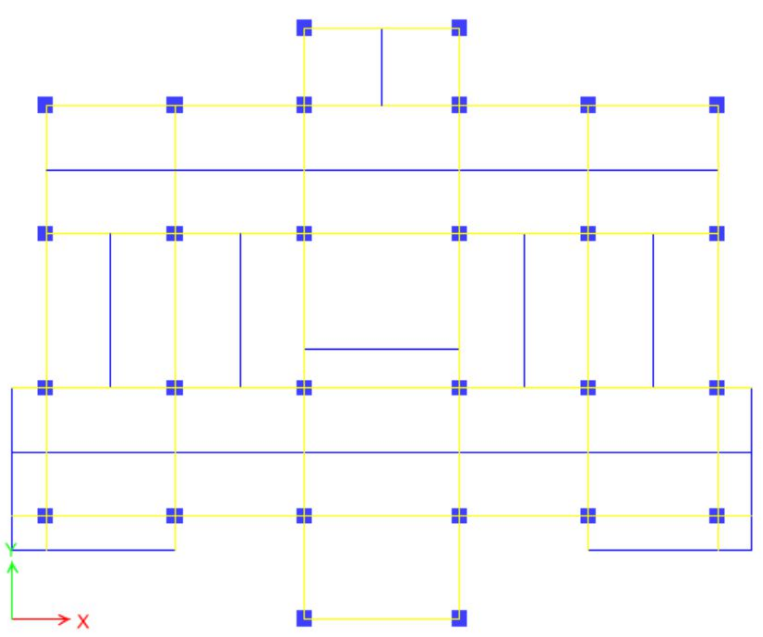

Fig. 13. Position of the Concrete Jacketing Column

Retrofit of the first floor columns is carried out using the Concrete Jacketing method on all existing columns because the concrete and steel quality in the column has decreased $[9,10]$. The Concrete Jacketing Column Position is shown in Fig. 13.

\subsubsection{Structural Retrofitting Modeling using Concrete Jacketing Method}

Retrofitting of the column using jacketing method is carried out by increasing the dimensions and adding steel reinforcement to the column with the following assumptions

- The planned jacketing column is $600 \times 600(\mathrm{~mm})$.

- The column quality to be achieved is $\mathrm{fc}^{\prime}=25 \mathrm{MPa}$.

- In order to reach a concrete quality of fc' $=25 \mathrm{MPa}$, the quality of the jacketing concrete used as an addition to the column dimensions is a minimum of $\mathrm{fc}^{\prime}=36 \mathrm{MPa}$. Calculation of the quality of the concrete jacketing is as follows:

- Column quality to be achieved $(\mathrm{A})=25 \mathrm{MPa}$

- Existing Concrete Quality (B) $=11.24 \mathrm{MPa}$

- Planned column area $(C)=600 \times 600=360,000 \mathrm{~mm}^{2}$

- Existing column area $(D)=400 \times 400=160,000 \mathrm{~mm}^{2}$

- Jacketing area $(E)=200,000 \mathrm{~mm}^{2}$

Quality of concrete jacketing:

$$
(\mathrm{D} \times \mathrm{B})+(\mathrm{E} \times \mathrm{X})=\mathrm{C} \times \mathrm{A}
$$

$(160,000 \times 11.24)+200,000 \times(X)=360,000 \times 25$

$$
\mathrm{X}=36 \mathrm{MPa}
$$

- The quality and amount of added steel reinforcement are the same as the existing one, that is fy= $350 \mathrm{MPa}$ with 12 D16.

From Figs. 14 and 15, it can be seen the assumption of the definition of the jacketing column in the ETABS software. Fig. 16 shows the comparison of the column cross-section between the existing column and the jacketing column.

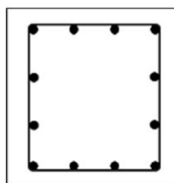

(a)

Existing

Column

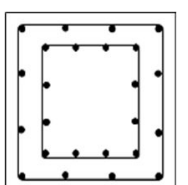

(b)

Concrete

Jacketing

Coluumn

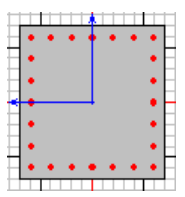

(c)
Jacketing

Column with

Evenly

Distributed

Reinforcement

Fig. 14.Conrete Jacketing Column Reinforcement Modeling

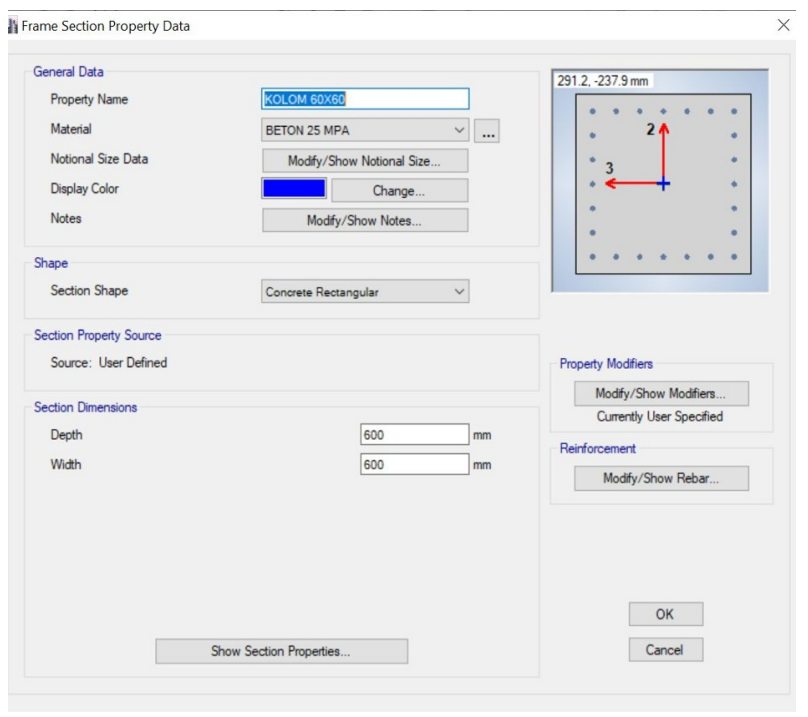

\begin{tabular}{|c|c|c|c|}
\hline \multicolumn{2}{|c|}{ EKSISTING } & \multicolumn{2}{|c|}{ JACKETING } \\
\hline b & $\begin{array}{ll}0 & 0 \\
\end{array}$ & 6 & 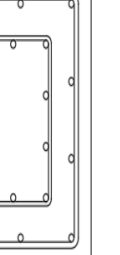 \\
\hline DIMENSION & $400 \times 400 \mathrm{~mm}$ & DIMENSION & $600 \times 600 \mathrm{~mm}$ \\
\hline ff' & 22,39 Mpa & $\mathrm{fc}^{\prime}$ & $25 \mathrm{Mpa}$ \\
\hline fy & $350 \mathrm{Mpa}$ & fy & $400 \mathrm{Mpa}$ \\
\hline COVER & $40 \mathrm{~mm}$ & COVER & $40 \mathrm{~mm}$ \\
\hline MAIN RENFORCED & $12 \mathrm{D} 16$ & MAN RENFORCED & $24 \mathrm{D16}$ \\
\hline SHEAR REIFFORCED & $\varnothing 10-100$ & SHEAR REIFFORCED & $010-100$ \\
\hline
\end{tabular}

Fig. 15. Concrete Jacketed Column Modeling

Fig. 16. The comparison of the Column Cross-section between the Existing Column and the Jacketed Column

\subsubsection{Retrofitted Column Capacity}

Fig. 17 shows the cross-sectional capacity of the column reinforced by the jacketing method. From the figure, it can be seen that all the P-M points on the graph have been in the interaction diagram, so that the column is able to withstand the working load. 


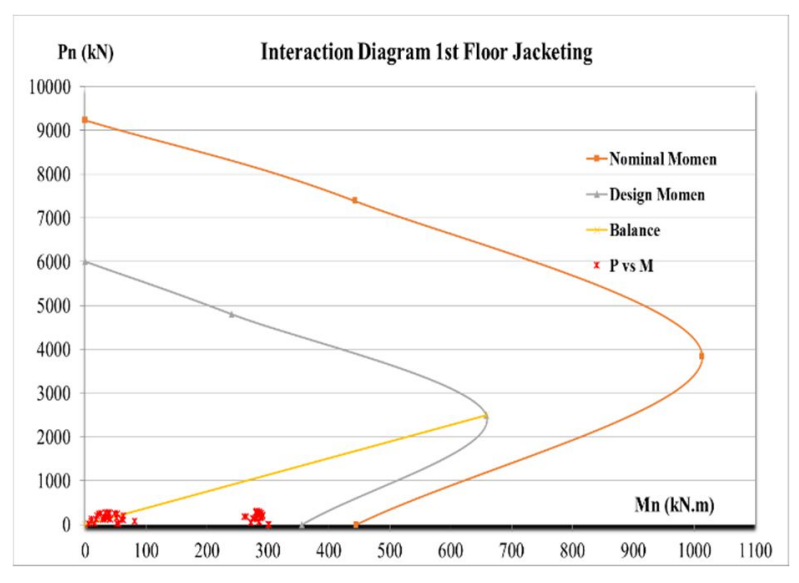

Fig. 17. P-M Interaction Diagram of Jacketed Column 600x600

\subsubsection{Inter Story Drift}

Retrofitting on the existing first floor column with the jacketing method also affects the building displacement, so it is necessary to check the displacement of the building structure. The calculation results of the inter story drift in the $\mathrm{X}$ and $\mathrm{Y}$ directions on the retrofitted building can be seen in Tables 13 and 14.

From Tables 13 and 14, it is clearly seen that the inter story drift that occurs have met the permit limit requirements.

Table 13. Inter story drift in $\mathrm{X}$ direction for retrofitted column

\begin{tabular}{|c|c|c|c|c|c|c|c|c|}
\hline \multirow{2}{*}{ Story } & \multirow{2}{*}{ Direction } & $\delta_{\mathrm{e}}$ & \multirow{2}{*}{$\mathrm{Cd}$} & $\delta_{\mathrm{er}}$ & $\Delta_{\mathrm{I}}$ & Height & $\Delta($ Limit) & \multirow{2}{*}{ Description } \\
\cline { 7 - 10 } & & $\mathrm{mm}$ & & $\mathrm{mm}$ & $\mathrm{mm}$ & $\mathrm{mm}$ & $\mathrm{mm}$ & \\
\hline 2 & $\mathrm{X}$ & 16.244 & 5.5 & 59.561 & 36.971 & 4000 & 40 & $0 \mathrm{~K}$ \\
\hline 1 & $\mathrm{X}$ & 6.161 & 5.5 & 22.590 & 22.590 & 4000 & 40 & $0 \mathrm{~K}$ \\
\hline 0 & $\mathrm{X}$ & 0 & 5.5 & 0.000 & 0.000 & 4000 & 40 & $0 \mathrm{~K}$ \\
\hline
\end{tabular}

Table 14. Inter Story drift in Y direction for retrofitted column

\begin{tabular}{|c|c|c|c|c|c|c|c|c|}
\hline \multirow{2}{*}{ Story } & \multirow{2}{*}{ Direction } & $\delta_{\mathrm{e}}$ & \multirow{2}{*}{$\mathrm{C}$} & $\delta_{\mathrm{ex}}$ & $\Delta_{\mathrm{Y}}$ & Height & $\Delta($ (limit) & Descripti \\
\cline { 6 - 9 } & & $\mathrm{mm}$ & & $\mathrm{mm}$ & $\mathrm{mm}$ & $\mathrm{mm}$ & $\mathrm{mm}$ & on \\
\hline 2 & $\mathrm{Y}$ & 16.131 & 5.5 & 59.147 & 36.938 & 4000 & 40 & $0 \mathrm{~K}$ \\
\hline 1 & $\mathrm{Y}$ & 6.057 & 5.5 & 22.209 & 22.209 & 4000 & 40 & $0 \mathrm{~K}$ \\
\hline 0 & $\mathrm{Y}$ & 0 & 5.5 & 0 & 0.000 & 4000 & 40 & $0 \mathrm{~K}$ \\
\hline
\end{tabular}

\section{Conclusion}

Based on the structural evaluation analysis conducted at the Nursing Faculty Building, the following conclusions can be drawn:

1. The quality of the existing concrete obtained from the hammer test results is $\mathrm{fc}^{\prime}=11.24 \mathrm{MPa}$, where this value is far below the concrete quality standard for reinforced concrete building structures (minimum $\mathrm{fc}^{\prime}$ $=17 \mathrm{MPa})$.
2. The structure of the existing first floor column, second floor plan column, and the initial design of the main and secondary beams are not able to withstand the working load.

3. The inter story drift in the existing building does not meet the permit limit requirements according to the Indonesian building standard.

4. Retrofitting of the building structure is designed by redesigning the Detail Engineering Design (DED) structure, where the existing first floor column is retrofitted by using jacketing method.

5. The retrofitted building structure has a strong enough capacity to carry the working load, and the inter story drift has met the permit limit requirements.

The authors would like to thanks Andalas University for financial support in publishing this article.

\section{References}

1. O.Dezardo, Feasibility Evaluation and Recommendation for Strengthening the Dean Building Structure of the Faculty of Nursing, Andalas University, (2016)

2. National Standardization Agency, Minimum Load for Planning of Buildings and Other Structures, SNI 1727:2020, Jakarta, BSN (2020)

3. National Standardization Agency, Procedure for Planning Earthquake Resistance for Building Structures, SNI 1726:2019, Jakarta, BSN (2019)

4. National Standardization Agency, Structural Concrete Requirements for Buildings, SNI 2847:2019, Jakarta, BSN (2019)

5. T. Boen, et al., How to Repair a Simple Building Damaged by an Earthquake, Jakarta (2009)

6. Central Public Works Department and Indian Building Congress, Handbook on Seismic Retrofit of Buildings. Association of Indian Institutes of Technology,India (2007)

7. R. Santhakumar, Retrofit of masonry buildings, Handb. Seism. Retrofit Build. (2007)

8. H. Khoeri, Selecting Methods for Repair and Reinforcement of Structures Due to Earthquake (Case Study at Bank Sulteng Palu), Journal of Construction, 12 (1) (2020)

9. J.T. Kaontole, M.D.J. Sumajouw, and R.S. Windah, Evaluation of Reinforced Concrete Columns Capacity Reinforced by the Concrete Jacketing Method, Civil Static, 3 (3) (2015)

10. F. S. Asmara, M. Ziddan, and A. Rosyidah, Improving the Strength of Existing Structures by Reinforcing Structures Using CFRP \& Concrete Jacketing, Teknika, 13 (02) (2019) 